\title{
'Florida Brilliance' Strawberry
}

\author{
Vance M. Whitaker, Natalia A. Peres, Luis F. Osorio, and Zhen Fan \\ Gulf Coast Research and Education Center, University of Florida, 14625 CR \\ 672, Wimauma, FL 33598
}

\section{Cecilia do Nascimento Nunes \\ Department of Cell Biology, Microbiology and Molecular Biology, University of South Florida, 4202 E. Fowler Avenue, Tampa, FL 33620}

\section{Anne Plotto}

U.S. Department of Agriculture Agricultural Research Service, U.S. Horticultural Research Laboratory, 2001 South Rock Road, Fort Pierce, FL 34945

\section{Charles A. Sims \\ Food Science and Human Nutrition Department, University of Florida, Gainesville, FL 32611}

Additional index words. Fragaria $\times$ ananassa, fruit breeding, small fruit

\begin{abstract}
The leading strawberry (Fragaria $\times$ ananassa) grown in Florida is currently 'Florida Radiance' (Chandler et al., 2009; U.S. Patent PP20,363), which was commercialized in 2009 and accounted for $\approx 50 \%$ of the acreage in west central Florida in 2018. This cultivar is preferred for its early and total yields; uniformly shaped, medium-sized and attractive fruit; and open plant architecture and long stems, which allow for efficient harvesting. Sweet Sensation ${ }^{\circledR}$ 'Florida127' (Whitaker et al., 2015; hereafter referred to as 'Florida127'; U.S. Patent PP25,574) is currently the second leading cultivar with $\approx 25 \%$ of the acreage in 2018-19. This cultivar complements the traits of 'Florida Radiance' with its large fruit size, excellent flavor and aroma, and robust plant. Although both leading cultivars have higher yields in late November and early December than previous cultivars, there is a pressing need for continued increases in early yield. Average prices have decreased during the Florida market window from late November through March in recent seasons, primarily due to Mexican imports (Wu et al., 2015). Thus, Florida growers must take maximum advantage of high prices at the beginning of the season when market supply is lowest.
\end{abstract}

\footnotetext{
Received for publication 25 June 2019. Accepted for publication 2 Aug. 2019.

We acknowledge David Moore and Teresa Seijo for significant contributions of data and analysis. Funding for this work was provided by the Florida Agricultural Experiment Station, the Florida Strawberry Research and Education Foundation, and the Florida Department of Agriculture and Consumer Services through the USDA Specialty Crop Block Grant program.

V.M.W. is the corresponding author. E-mail: vwhitaker@ufl.edu.

This is an open access article distributed under the CC BY-NC-ND license (https://creativecommons. org/licenses/by-nc-nd/4.0/).
}

'Florida Brilliance' strawberry (U.S. Patent PP30,564) has demonstrated high early-season yields and excellent overall fruit quality and disease resistance in experimental trials. Trials have been conducted on the research plots of the University of Florida Gulf Coast Research and Education Center (GCREC) (Wimauma, FL); at the Florida Strawberry Growers Association (FSGA) headquarters in Dover, FL; and in trials on several commercial farms in west central Florida and southern Spain.

\section{Origin}

'Florida Brilliance' strawberry originated from a 2013 cross between unreleased selection FL 11.31-14 (female parent) and unreleased selection FL 10-153 (male parent) (Fig. 1). FL 11.31-14 was chosen as a parent for its yield, shape, and fruit firmness, whereas FL 10-153 was chosen primarily for its disease resistance and uniform fruit color. Winter$\operatorname{star}^{\mathrm{TM}}$ 'FL 05-107' is both a maternal and paternal grandparent, contributing early yield and desirable plant architecture, whereas the other grandparents arose from diverse pedigrees (Fig. 1). Seeds from this cross were germinated and seedlings evaluated during the 2013-14 season. 'Florida Brilliance' was evaluated as advanced selection FL 13.26-134 in 2014-15 in a clonally replicated small-plot test where it was noted for high early yields and a high percentage of marketable fruit.

During the 2015-16, 2016-17, and 201718 seasons, yield and fruit quality data were collected from a replicated trial conducted at the GCREC. Field plots were prepared and maintained according to current commercial practices for annual strawberry plasticulture in Florida. Beds were spaced $1.2 \mathrm{~m}$ on center and were $90 \mathrm{~m}$ long, $70 \mathrm{~cm}$ wide, $15 \mathrm{~cm}$ high at the edges and $18 \mathrm{~cm}$ high in the center; they were covered with a single layer of black, high-density polyethylene mulch. Preplant fumigation consisted of a 65:35 mixture of 1,3-dichloropropene and chloropicrin (Telone
C35, Dow AgroSciences). Each bed contained two rows of plants spaced $38 \mathrm{~cm}$ apart within rows and $28 \mathrm{~cm}$ apart between rows within beds. All trials were conducted using bare-root plants. Five replicate plots (10 plants per plot) of each genotype were planted in a randomized complete block design at the GCREC. The trials were planted between Oct. 9 and 11 in each year; the commercial planting period ranges from $\approx 25$ Sept. to 20 Oct. Overhead irrigation from impact sprinklers was applied for plant establishment during daylight hours for up to $10 \mathrm{~d}$ after transplanting, after which water and fertilizer were applied exclusively through a single drip tape.

All ripe fruit (at least three-quarters red) were harvested, graded, counted, and weighed twice a week from December through March. Fruits that were diseased, misshapen, small $(<10$ $\mathrm{g}$ ), or rain damaged were considered unmarketable, and the remaining fruit were weighed to determine the marketable yield in grams on a per plant basis. Fresh fruit were transported by air-conditioned vehicle to the U.S. Department of Agriculture Agricultural Research Service, U.S. Horticultural Research Laboratory in Fort Pierce, FL, once each month for flavor evaluations by a trained sensory panel and measurement of soluble solids content (SSC), $\mathrm{pH}$, titratable acidity ( $\%$ citric acid equivalents), and firmness on fruit from the same field plots previously described (Plotto et al., 2013). Two to three hundred fruit of each cultivar from a separate GCREC field were also transported to the Food Science and Human Nutrition Department of the University of Florida in Gainesville, FL, for consumer sensory evaluation. The ratings of more than 100 untrained panelists were collected for overall acceptability, texture acceptability, flavor intensity, sweetness intensity, and sourness intensity using the methods and rating scales of Ubeda (2011) and Kalva et al. (2014). Commercially packed fruit in 1-lb (454-g) plastic containers were also transported on three dates in 2016-17 and 2017-18 to the Food Quality Laboratory of the University of South Florida for analysis of quality attributes over time during cold storage at $1{ }^{\circ} \mathrm{C}$ and $85 \%$ relative humidity. Weight loss and quality ratings were collected using previously published methods (Nunes and Emond, 2007; Nunes and Delgado, 2014).

Separate field trials were conducted during the 2016-17 and 2017-18 seasons to determine resistance to fruit, foliar, and crown pathogens. Inoculation and rating methods for anthracnose fruit rot (caused by Colletotrichum acutatum species complex), charcoal rot (caused by Macrophomina phaseolina), Phytophthora crown rot (caused by Phytophthora cactorum), and Colletotrichum crown rot (caused by $\mathrm{Col}$ letotrichum gloeosporioides species complex) were described in Seijo et al. (2011), Mertely et al. (2014a, 2014b), and MacKenzie et al. (2006). Foliar powdery mildew (caused by Podosphaera aphanis) was evaluated in a high tunnel with increased relative humidity, and percent leaf area with mycelia was visually estimated. Natural disease incidence was determined for powdery mildew and botrytis fruit rot (caused by Botrytis cinerea). 


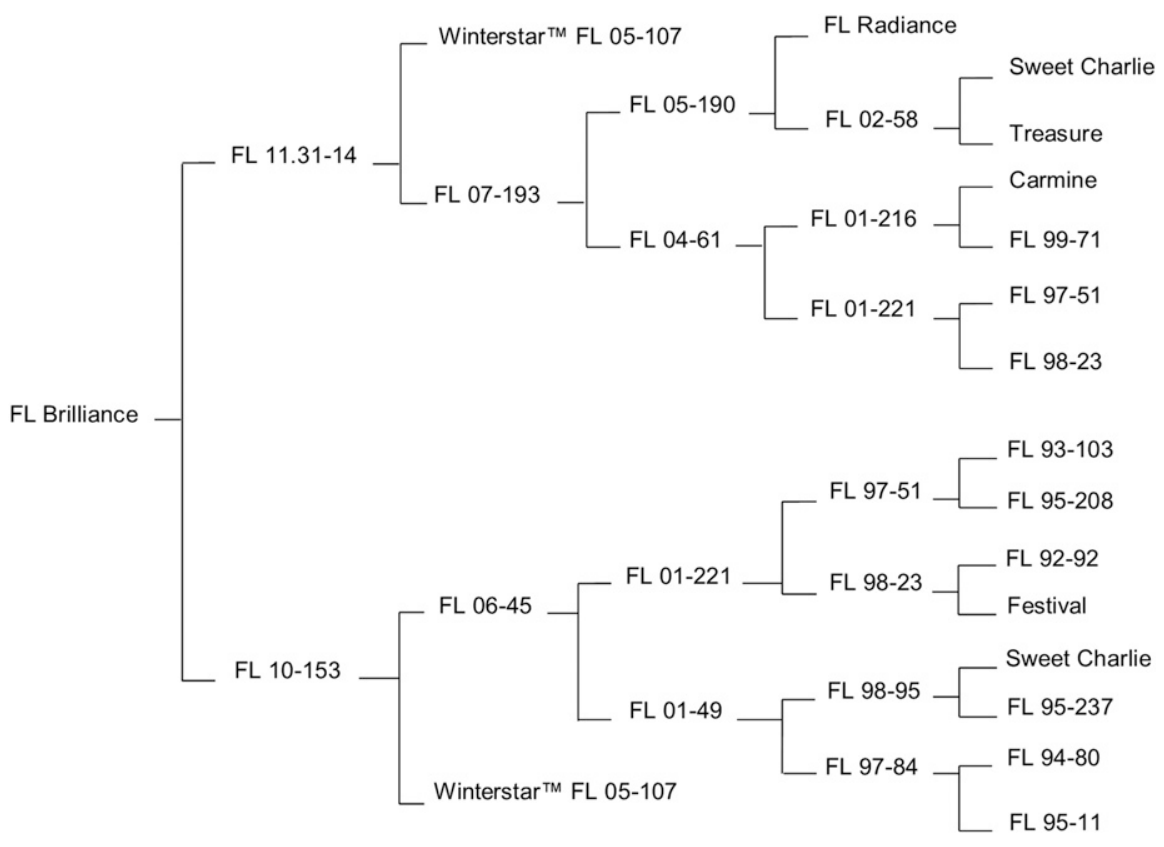

Fig. 1. Pedigree of 'Florida Brilliance' strawberry. The female parent is listed on the upper side of each bifurcation.

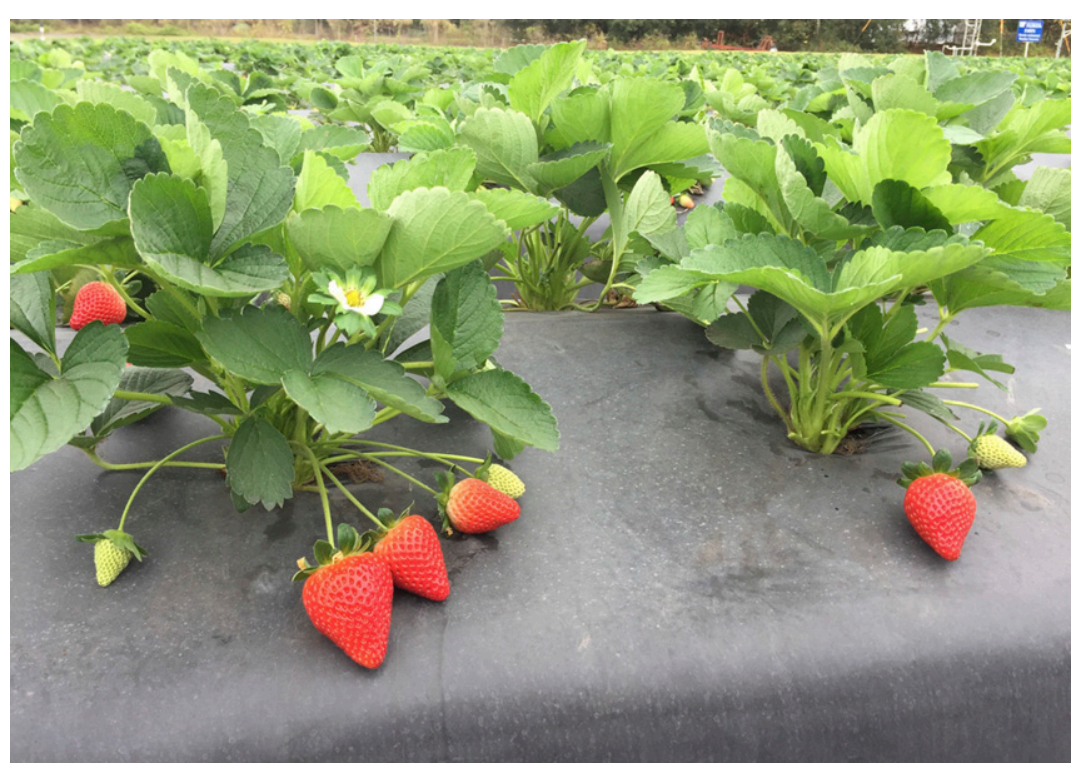

Fig. 2. Plants and fruit of 'Florida Brilliance' strawberry on Dec. 2016 on a farm near Plant City, FL.
In all statistical analyses blocks were considered as fixed effects, and mean separations were only performed if genotype effects were significant. Residuals were checked for normality and homogeneity, and percentage data were modeled with GLIMMIX using logit link functions and binomial distributions.

\section{Description}

'Florida Brilliance' is a short-day strawberry adapted to annual plasticulture growing systems for winter and early spring production. The plant is moderately compact with open architecture, allowing air movement and visualization of the fruit (Fig. 2). Long pedicels allow the fruit to be easily harvested. 'Florida Brilliance' produces moderately firm and juicy fruit that are broadconic in shape with a medium-green (colorimeter $\left.L^{*}=37.7, a^{*}=-14.4, b^{*}=18.8\right)$ calyx that is slightly reflexed. The redness of the fruit is medium externally $\left(\mathrm{a}^{*}=34.7\right)$, with moderate internal redness $\left(\mathrm{a}^{*}=22.7\right)$ similar to 'Florida Radiance'. The achenes are notably sunken, deeper than the commercial standards, resulting in a glossy appearance due to curvatures of the skin that reflect light in many directions. Fruit size is medium-large, with average fruit weight between 'Florida Radiance' and 'Florida127' (Table 1).

Two consumer panels gave similar ratings to 'Florida Brilliance' and 'Florida Radiance' except that 'Florida Brilliance' had higher sweetness and lower sourness than 'Florida Radiance' in the second panel (Table 2). Similar results were observed in trained sensory panels conducted on nine harvest dates over three seasons (Table 3). Sweetness and strawberry flavor intensity ratings were usually not different from 'Florida Radiance', but sweetness was occasionally higher and sourness lower. This is consistent with similar SSC for 'Florida Brilliance' and 'Florida Radiance' (Table 4). 'Florida Brilliance' had significantly higher fruit firmness than 'Florida Radiance' on four of nine harvest dates according to the trained sensory panel (Table 3), but no clear pattern was discernable for instrumental firmness (Table 4).

Rankings of fruit weight loss for the three cultivars varied with harvest date when cold stored for $9 \mathrm{~d}$. Overall, 'Florida Brilliance'

Table 1. Marketable yield and average fruit weight of 'Florida Brilliance', 'Florida127', and 'Florida Radiance' at the University of Florida Gulf Coast Research and Education Center at Wimauma, FL, during three seasons.

\begin{tabular}{|c|c|c|c|c|c|c|c|c|c|c|c|c|c|c|}
\hline \multirow{4}{*}{$\begin{array}{l}\text { Cultivar } \\
\text { FL Brilliance }\end{array}$} & \multicolumn{12}{|c|}{ Marketable yield (g/plant) } & & \\
\hline & \multicolumn{2}{|c|}{ November } & \multicolumn{2}{|c|}{ December } & \multicolumn{2}{|c|}{ January } & \multicolumn{2}{|c|}{ February } & \multicolumn{2}{|c|}{ March } & \multicolumn{2}{|c|}{ Total } & \multicolumn{2}{|c|}{$\mathrm{Wt} /$ fruit $(\mathrm{g})^{\mathrm{z}}$} \\
\hline & & & & & & & & & & & & & & \\
\hline & 70.0 & $a^{y}$ & 132.1 & $\mathrm{a}$ & 49.8 & $\mathrm{a}$ & 177.0 & $\mathrm{a}$ & 209.6 & $\mathrm{a}$ & 638.6 & $\mathrm{a}$ & 20.2 & $\mathrm{~b}$ \\
\hline FL Brilliance & 30.3 & $\mathrm{a}$ & 125.3 & $\mathrm{a}$ & 154.8 & $\mathrm{~b}$ & 452.1 & $\mathrm{a}$ & 251.9 & $\mathrm{a}$ & 1014.4 & $\mathrm{a}$ & 20.7 & $\mathrm{~b}$ \\
\hline Florida127 & 14.1 & $\mathrm{~b}$ & 115.2 & $\mathrm{a}$ & 211.9 & $\mathrm{a}$ & 428.7 & $\mathrm{a}$ & 197.1 & $\mathrm{~b}$ & 967.0 & $\mathrm{ab}$ & 23.5 & $\mathrm{a}$ \\
\hline FL Radiance & 6.3 & $\mathrm{~b}$ & 102.3 & $\mathrm{a}$ & 157.2 & $\begin{array}{l}\mathrm{b} \\
2\end{array}$ & $\begin{array}{l}413.9 \\
18\end{array}$ & $\mathrm{a}$ & 174.1 & $\mathrm{~b}$ & 853.8 & $\mathrm{~b}$ & 18.8 & $\mathrm{c}$ \\
\hline Florida127 & 6.5 & $a b$ & 95.4 & $\mathrm{a}$ & 167.9 & $\mathrm{a}$ & 397.3 & $\mathrm{a}$ & 193.5 & $\mathrm{a}$ & 860.4 & $\mathrm{a}$ & 28.4 & $\mathrm{a}$ \\
\hline FL Radiance & 1.7 & $\mathrm{~b}$ & 32.9 & $\mathrm{~b}$ & 96.5 & $\mathrm{~b}$ & 358.9 & $\mathrm{a}$ & 230.7 & $\mathrm{a}$ & 720.7 & $\mathrm{~b}$ & 24.4 & $\mathrm{~b}$ \\
\hline
\end{tabular}

${ }^{\mathrm{z}}$ Mean fruit weight was determined by dividing total marketable fruit yield per plot by total marketable fruit number per plot.

${ }^{\mathrm{y}}$ Mean separation within columns is by Tukey's honestly significant difference test, $P \leq 0.05$. Yield data for 'Florida Radiance' was not available in $2015-16$. 
Table 2. Consumer sensory ratings for 'Florida Brilliance', 'Florida127', and 'Florida Radiance' based on the ratings of $>100$ untrained panelists on 7 Feb. and 14 Feb. 2017.

\begin{tabular}{|c|c|c|c|c|c|c|c|c|c|c|}
\hline$\overline{\text { Cultivar }}$ & Overal & tability ${ }^{z}$ & Textu & ptability & Flav & nsity $^{y}$ & Sweet & tensity & Sourn & tensity \\
\hline & & & & & & & & & & \\
\hline FL Brilliance & 31.8 & $b^{x}$ & 32.7 & $\mathrm{~b}$ & 33.9 & $a b$ & 30.0 & $\mathrm{~b}$ & 18.1 & $a b$ \\
\hline Florida127 & 38.4 & $\mathrm{a}$ & 38.0 & $\mathrm{a}$ & 36.4 & $\mathrm{a}$ & 34.3 & $\mathrm{a}$ & 14.8 & $b$ \\
\hline FL Radiance & 30.2 & b & 33.6 & $\mathrm{ab}$ & 30.0 & $\mathrm{~b}$ & 28.5 & $\mathrm{~b}$ & 18.4 & $\mathrm{a}$ \\
\hline & & & & & & & & & & \\
\hline FL Brilliance & 28.0 & $a b$ & 29.6 & $\mathrm{~b}$ & 29.6 & $a b$ & 26.9 & $\mathrm{a}$ & 15.2 & $\mathrm{~b}$ \\
\hline Florida127 & 33.4 & $\mathrm{a}$ & 36.6 & $\mathrm{a}$ & 32.5 & $\mathrm{a}$ & 29.7 & $\mathrm{a}$ & 15.3 & $a b$ \\
\hline FL Radiance & 25.4 & $\mathrm{~b}$ & 30.9 & $\mathrm{~b}$ & 27.3 & $\mathrm{~b}$ & 22.5 & $\mathrm{~b}$ & 18.6 & $\mathrm{a}$ \\
\hline
\end{tabular}

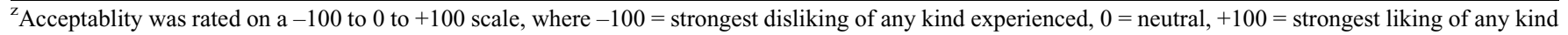
experienced.

y Intensity was rated on a 0 to 100 scale, where $0=$ no sensation, $100=$ strongest sensation of any kind experienced.

${ }^{\mathrm{x}}$ Mean separations are within columns by Tukey's honestly significant difference test, $P \leq 0.05$.

Table 3. Trained sensory panel ratings ( $0-10$ linear scale, with increasing intensity) for 'Florida Brilliance', 'Florida127', and 'Florida Radiance' on nine harvests over three seasons. Fruit samples from the same harvest and field replication were measured for fruit chemical attributes shown in Table 4.

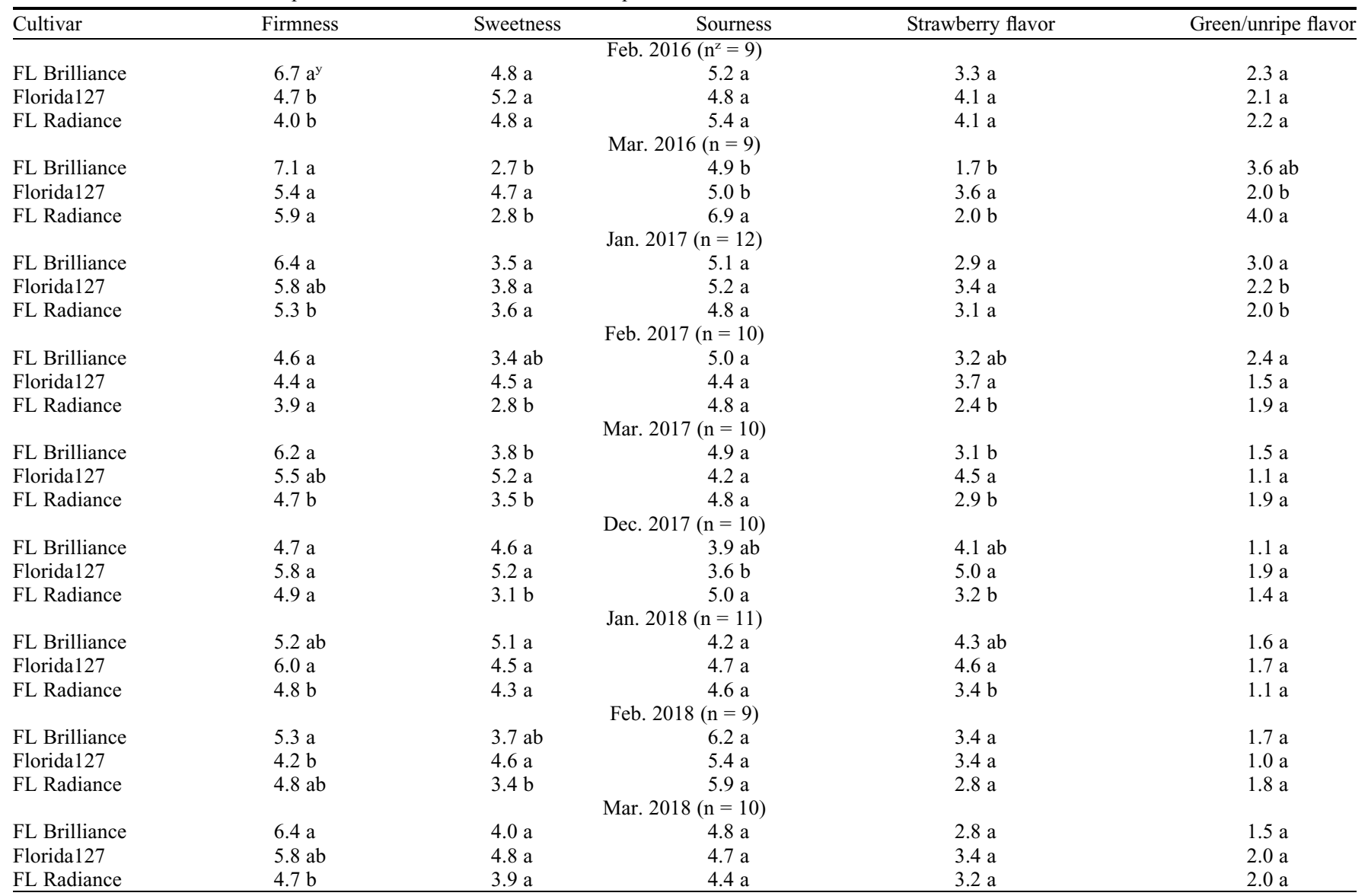

${ }_{\mathrm{Z}}^{\mathrm{Z}}$ Number of trained panelists.

${ }^{\mathrm{y}}$ Mean separations within harvest dates and columns are by Tukey's honestly significant difference test, $P \leq 0.05$.

had lower weight loss compared with the commercial standards and showed less shriveling of the fruit surface and calyx than 'Florida Radiance' and 'Florida127' (data not shown).

\section{Field Performance}

In replicated trials, early and total yields of 'Florida Brilliance' were higher than 'Florida Radiance' in both seasons in which they were tested together, whereas November yields were significantly higher than for 'Florida127' in two of three sea- sons (Table 1). Temperatures from October to December in 2015-16 were higher on average than in 2016-17, contributing to overall lower yields during this year. Thus, the fall temperatures in the first year of testing were more similar to that experienced on an earlier planting date. An onfarm trial with a planting date of 25 Sept. 2016 was established to test the suitability of 'Florida Brilliance' for early planting, in which it had higher early and total yield than 'Florida Radiance' (Fig. 3). Although elongated, unmarketable fruit were observed for 'Florida Radiance' in November and December, 'Florida Brilliance' maintained an exceptionally consistent conical shape throughout the season in all trials.

The disease-resistance profile of 'Florida Brilliance' was similar to that of 'Florida127' with two notable exceptions (Table 5). The incidence of anthracnose fruit rot for 'Florida Brilliance' was higher than 'Florida127' in both seasons but was not different from 'Florida Radiance', which is considered moderately resistant. Conversely, the incidence of powdery mildew was lower for 'Florida Brilliance' than for 'Florida127' in both seasons. 'Florida Brilliance' also 
Table 4. Soluble solids content (SSC), pH, titratable acidity (TA), SSC/TA, and firmness for 'Florida Brilliance', 'Florida127', and 'Florida Radiance' fruit for nine harvests over three seasons.

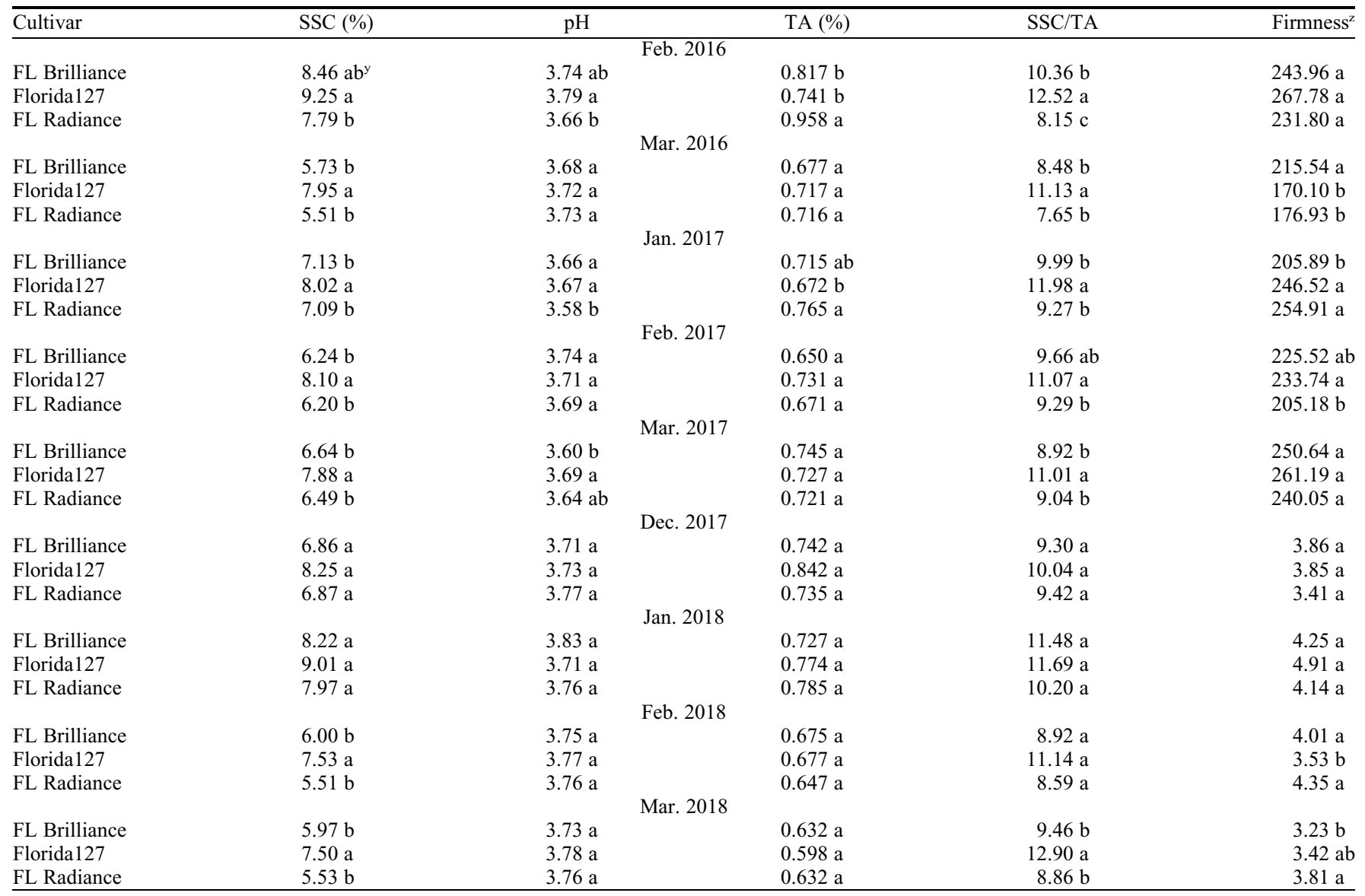

${ }^{\mathrm{z} F i r m n e s s}$ in 2016 and 2017 measured with FirmTech 2 (Bioworks, Wamego, KS) and in Dec. 2017 and 2018 with Texture Analyzer XT2 (Texture Technologies Corp. Ltd., Hamilton, MA). Units are N. $\mathrm{m}^{-1}$ in 2016-17 and N in Dec. 2017 and 2018.

${ }^{\mathrm{y}}$ Mean separations within harvest dates and columns are by Tukey's honestly significant difference test, $P \leq 0.05$.

Table 5. Disease incidence and mortality for 'Florida Brilliance', 'Florida127', and 'Florida Radiance' from field trials over two harvest seasons. Incidence of anthracnose fruit rot (caused by Colletotrichum acutatum) and botrytis fruit rot (caused by Botrytis cinerea) are based on twice-weekly fruit harvests. Incidence of powdery mildew (caused by Podosphaera aphanis) describes foliar symptoms only. Mortality due to Colletotrichum crown rot (caused by Colletotrichum gloeosporioides), Phytophthora crown rot (caused by Phytophthora cactorum), and charcoal rot (caused by Macrophomina phaseolina) was assessed at the conclusion of the harvest season or when mortality in highly susceptible individuals reached $75 \%$ or greater.

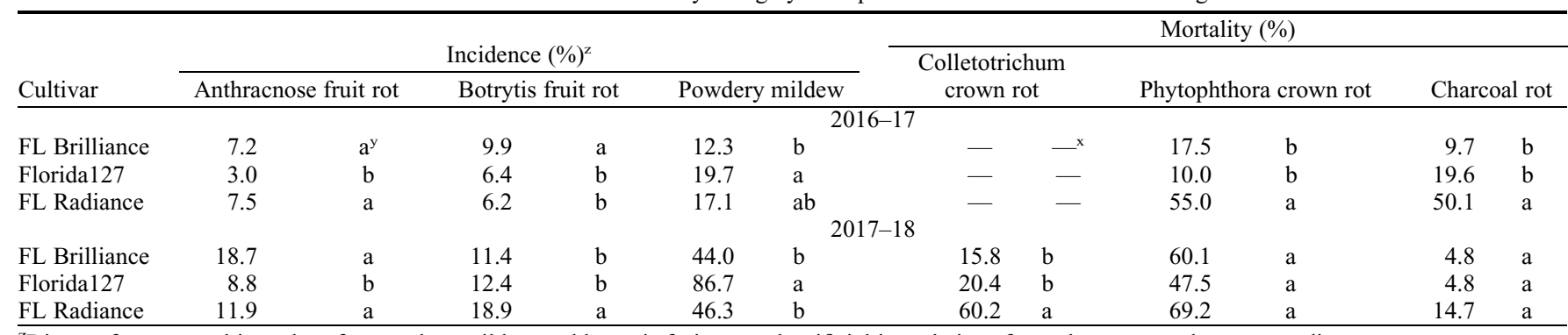

${ }^{\mathrm{z}}$ Disease from natural inoculum for powdery mildew and botrytis fruit rot and artificial inoculations for anthracnose and crown rot diseases.

${ }^{\mathrm{y}}$ Means are based on four replications of 10 to 12 plants each. Mean separations within columns is by Tukey's honestly significant difference test, $P \leq 0.05$.

$x_{-}=$data not available.

displayed resistance to charcoal rot in both years.

\section{Commercialization}

'Florida Brilliance' was approved for release by the Florida Agricultural Experiment Station in 2017. U.S. Patent PP30,564 was granted in 2019. Plant breeder's rights applications have been filed in foreign territories.
Information on nurseries licensed to propagate this cultivar can be obtained from Florida Foundation Seed Producers, Inc., P.O. Box 110200, Gainesville, FL, 32611 (http://ffsp.net).

\section{Literature Cited}

Chandler, C.K., B.M. Santos, N.A. Peres, C. Jouquand, A. Plotto, and C.A. Sims. 2009.
'Florida Radiance' strawberry. HortScience 44:1769-1770.

Kalva, J.J., C.A. Sims, L.A. Puentes, D.J. Snyder, and L.M. Bartoshuk. 2014. Comparison of the hedonic general labeled magnitude scale with the hedonic 9-point scale. J. Food Sci. 79:S238S245.

MacKenzie, S.J., D.E. Legard, L.W. Timmer, C.K. Chandler, and N.A. Peres. 2006. Resistance of strawberry cultivars to crown rot caused by 


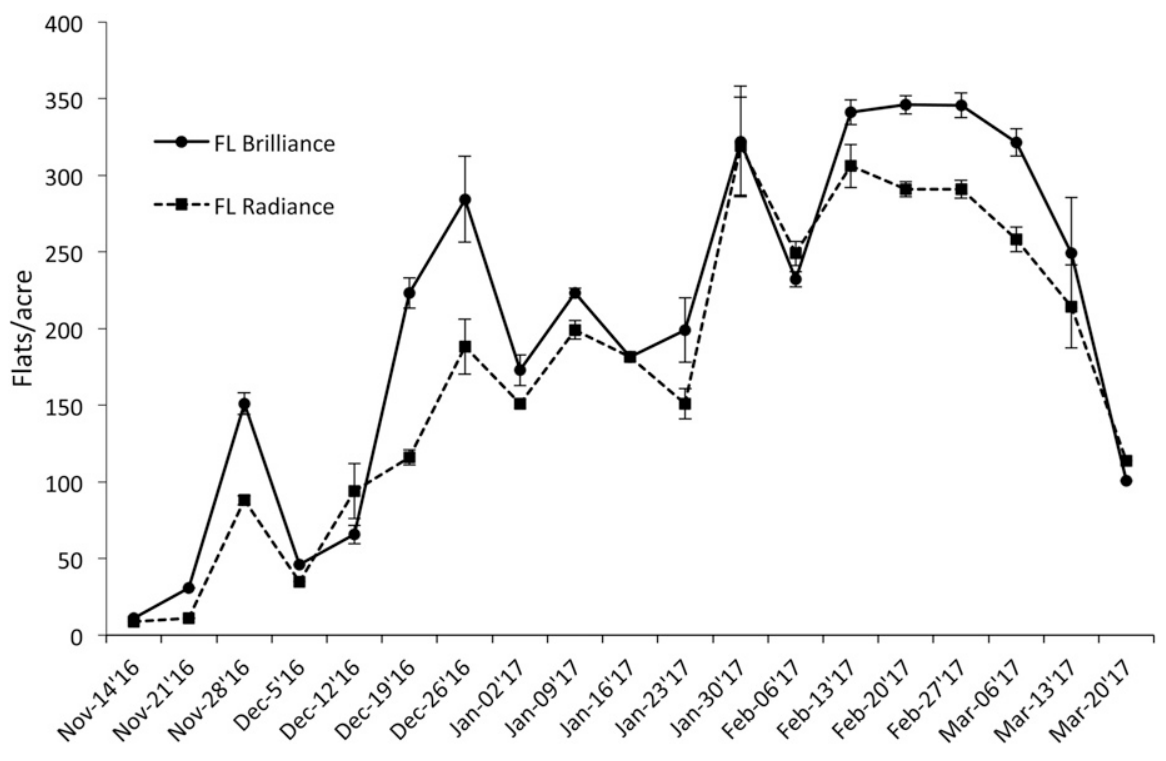

Fig. 3. Marketable yield of 'Florida Brilliance' and 'Florida Radiance' in a replicated, on-farm trial (two replications with 250 plants/rep) near Plant City, FL, during the 2016-17 season, with a planting date of 25 Sept. 2016. One flat $=$ eight 454-g plastic containers. Bars represent standard errors.

Colletotrichum gloeosporioides isolates from Florida is nonspecific. Plant Dis. 90:1091-1097. Mertely, J.C., T. Seijo, R. Martin, and N.A. Peres. 2014a. Evaluation of chemical and biological treatments for charcoal rot control in annual strawberry, 2013-14. Plant Dis. Mgmt. Rep.
Rep. 8:SMF027. Online publication. doi: 10.1094/PDMR08.

Nunes, M.C.N. and A. Delgado. 2014. Quality of organic compared to conventionally grown strawberries at the retail level. Acta Hort. 1049:723-729.

Nunes, M.C.N. and J.P. Emond. 2007. Relationship between weight loss and visual quality of fruits and vegetables. Proc. Annu. Meet. Fla. State Hort. Soc. 120:235-245.

Plotto, A., E. Baldwin, J. Bai, J. Narciso, V.M. Whitaker, and C.K. Chandler. 2013. Update on sensory evaluation of University of Florida strawberry selections. Proc. Annu. Meet. Fla. State Hort. Soc. 126:247-250.

Seijo, T., J. Mertely, V.M. Whitaker, and N Peres. 2011. Evaluation of strawberry cultivars and advanced breeding lines for field resistance to anthracnose and botrytis fruit rots, 2009-10. Plant Dis. Mgmt. Rep. 5:SMF020. Online publication. doi: 10.1094/ PDMR05

Ubeda, A.B. 2011. Sensory and chemical analysis of heirloom tomatoes: In search of a better tomato. Univ. of Florida, Gainesville, MS Thesis.

Whitaker, V.M., C.K. Chandler, N.A. Peres, M.C.N. Nunes, A. Plotto, and C. Sims. 2015. Sensation $^{\mathrm{TM}}$ 'Florida127' Strawberry. HortScience 50:1088-1091.

Wu, F., Z. Guan, and V.M. Whitaker. 2015. Optimizing yield distribution under biological and economic constraints: Florida strawberries as a model for perishable commodities. Agr Syst. 141:113-120. 